\title{
中枢性平衡障害例での滑動性眼球運動における予測制御
}

\author{
大橋 直樹・水越 鉄理
}

\section{Examination of the Predictive Mechanism in Smooth Pursuit in Disequilibrium Patients with Central Lesions}

\author{
Naoki Ohashi and Kanemasa Mizukoshi \\ (Toyama Medical and Pharmaceutical University)
}

\begin{abstract}
Previously, we explained the system we developed to examine the predictive function in smooth pursuit and reported that the phase lag is small if the predictive mechanism is functioning normally. We performed the same examination on disequilibrium patients with the central lesions. The qualitative judgment of ETT in these patients was designated as "saccadic pursuit pattern". The results indicated that the phase lag is significantly greater in these patients. This indicates that the predictive mechanism in smooth pursuit is disordered in disequilibrium patients with the central lesions.
\end{abstract}

Key words: smooth pursuit, phase lag, saccadic pursuit pattern

はじめに

視標運動の周波数が比較的小さい場合には, 随意性の滑動性眼球運動が働いて視標を中心窩 で捕足するが，視標の運動が速い場合には前庭 動眼反射が働いて網膜上で映像が動かない上う な機構が作動している.すなわち滑動性眼球運 動は前庭動眼反射と共に代償性眼球運動に関与 している1).ところで, 視標運動の凬波数が比 較的小さい場合には眼球運動は円滑でありほぼ 視標運動に近似した眼球運動が認められる.こ れは, 視標の位置を予測する予測制御機構が正 常に機能するからであると言われている。した がって滑動性眼球運動にあってはこの予測制御 機構がとりわけ重要であると言われている2). ところが従来の滑動性眼球運動検査ではどのパ ラメーターが予測制御機構の正常な働きを代表 寸るかが不明であった。そこで私達は視標運動
の方向が pseudo-random に変化し，方向の変 化についての予測が出来にくい視標運動を開発 し，正常被験者での検討を行い報告した3)。本 論文では中枢性平衡障害例での検査を行ったの で報告する。

\section{方法}

pseudo-random に視標の方向が变化する視 標運動（ランダム正弦波）を開発し，眼球運動 の視標運動に対する位相差を算出した。（視標 運動の開発, 眼球運動の分析については著者に より既に報告された別紙を参照されたい(4)5)． 今回検討した症例は神経耳科学的に中枢性平衡 障害と診断された21例であり（表 1 ），記録紙 上での滑動性眼球運動の定性分析はすべての症 例で saccadic patternを示していた.

結果 正常被験者 23 人での眼球運動の定量分析では 
視標運動の方向の変化が pseudo-random な正 弦波部分（図1 PRE-) と方向の変化が periodic である正弦波部分（図 $1 \mathrm{PRE}+$ ） と の間では視標運動に対する眼球運動の位相差の みに，有意差が視標運動の基本正弦波周波数 $1.2 \mathrm{~Hz}$ 以上で認められた。そこで本論文では 基本周波数 $1.2 \mathrm{~Hz}$ 以上の位相差について, 正 常被験者 23 人から得られた值と中枢性平衡障害 21人から得られた值について $\mathrm{T}$ 検定を行った. 図 1 に示すように視標運動の方向の変化が periodic でかつ predictive な予測制御可能な正 弦波部分 $(\mathrm{PRE}+)$ でも, 視標運動の方向の変 化が pseudo-random な予測制御不可能な正弦 波部分 (PRE-) での位相差も共に病的症例で

表 1

\begin{tabular}{cc}
\hline \hline 症例 : 小脳脳幹障害 & 11 \\
脊䣯小脳変性症 & 6 \\
脳血管障害 & 3 \\
そ の 他 & 1 \\
\hline 合 $\quad$ 計 & 21 例
\end{tabular}

は有意に大きかった。すなわちこれらの中枢性 平衡障害例では, 滑動性眼球運動機構の予測制 御機構が障害されていたと推察された。

\section{考察}

滑動性眼球運動は servomechanism と考学ら れ，網膜上を横切る target slip の速度 (retinal error velocity，REV) を入力として利用してお ク，結果として眼球運動速度を視標運動速度に 一致するように保持している。そして REV は 眼球運動の速度とは一定の傾向にはないが，視 標運動の振幅の大小に関わらず眼球運動の加速 度と REV が一定の傾向を示した。これらの結 果から視標運動が predictive で予測制御が働い ている場合には滑動性眼球運動での gain の保 持は REV によって生じた眼球運動加速度にあ る程度依存していると言われている。すなわち positive feedback 機構が neural predictor とし て機能していると報告されている6)。この予測 制御機構は predictor ${ }^{7}$, , a long-term learning process $^{8)}$, an internal model ${ }^{9)}$ 等と報告者によ って様々な名称で呼ばれ，入力系と出力系の間

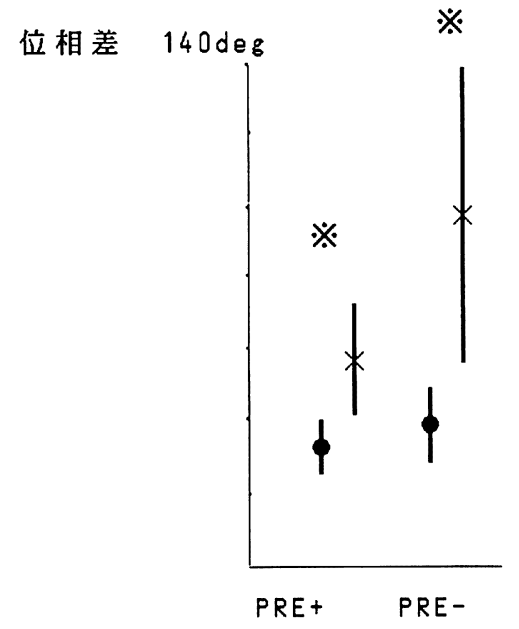

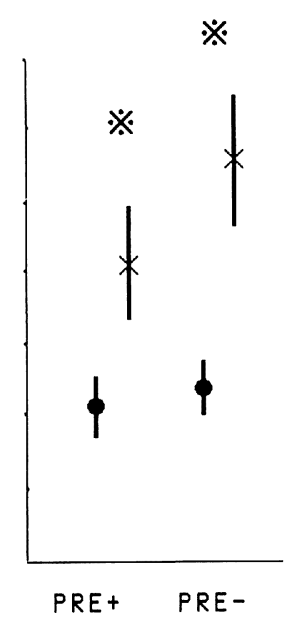

1. $4 \mathrm{~Hz}$
$※: p<0.01$

1. $2 \mathrm{~Hz}$

図 1 縦軸は位相差を degree で示した. PRE+ は予測制御可能な正弦波部分, PRE一は予測制 御ができにくい pseudo-random な正弦波部分を示す.図左は基本周波数 $1.2 \mathrm{~Hz}$ の, 右は 1 . $4 \mathrm{~Hz}$ の位相差を平均士標準偏差で示した. ・恃正常被検者 23 人の $\times$ は中枢障害例 21 人の平 均値を示す。 
に介在する制御機構の中に存在すると言われて いる6).ところで固視の目的は最終的には視力 の維持にあり, 滑動性眼球運動の予測能力は結 局この点に帰着するとされて抢り，視力の維持 は位相を最小にし振幅比を最大にすることによ って達成されると報告されている，さらに正弦 波の視標運動では良好な視力は $0.7 \mathrm{~Hz}$ までは 保たれ，この周波数までの位相差は最小に保持 される10)。ところで予測制御機構の研究には, 予測制御機構が十分に作動できない視標運動を 作成しこの時の眼球運動を記録分析することで 研究されてきた。従来の報告では unpredictable な視標運動は white noise や band noise が使用された778)。しかしこれらの方法では特 別な装置が必要でありまた分析方法も複雑にな る.そこで比較的手ごろに検查可能であり，か つ分析方法が容易なように，マイコンを応用し て視標運動の方向の変化のみがランダムに変化 する視標運動を作成した。その結果予測制御機 構が十分に機能していることは少なくとも本方 法では視標との位相を小さくするよらな機構が 働くことであると結論した ${ }^{3)}$.

ところで今回分析した中枢性平衡障害症例で は視標に対する位相差が，正常被験者に比較し て有意に大きく，これらの中枢性平衡障害例で は予測制御機構が障害されていると推察された。 視標に対する位相差が大きいために foveal pursuit が十分に機能せず saccade を発現させる position error の域值が低下し11), catch up saccade が働いて, 眼球運動が saccadic pattern を 示したものと推察した。ささらに位相の遅れは視 力の低下につながり，中心窩視の基本的な機能 が低下したことを意味する10) と推論した。

ところで滑動性眼球運動では initiation が最 初に働き眼球運動を始動させ，ついで maintenance の状態が維持されると言われている. velocity predictor により速度命令が発生され， この速度命令によって視標は fovea の tolerance zone に維持される. そして最終的に は retina 上の target slip ではなく foveaに対す
る相対的な position error で連続的に update さ れると報告されている11). すなわち滑動性眼球 運動で十分に予測制御機構が作動しているのは initiation でなく, maintenance に移行してか らであり，滑動性眼球運動の特に予測制御機構 の研究にはこの点に注意を払ら必要がある。つ まり視標が運動を開始してからどの時点が maintenance なのかについての詳細な検討が今後の 課題である。

$$
\text { まとめ }
$$

ETT で眼球運動が saccadic pattern を示し た中枢性平衡障害例では眼球運動の位相の遅れ が著明であり，予測制御機構の障害が認められ た.この予測制御機構の障害のために foveal pursuit が十分に機能せず saccade を発現させ る position error の域值が低下した ${ }^{11)}$. そして 結果として catch up saccade が働いて, 眼球運 動が saccadic patternを示したと結論した.

\section{参考文献}

1）篠田義一：眼球運動の生理学 - 眼球運動の神経 学 (小松崎篤, 篠田義一, 丸尾敏夫編). $1 \sim 147$ 頁, 医学書院, 東京, 1985.

2) Becker W : Discussion summary. Progress in Oculomotor Research. (ed by Fucks AF and Becker W). pp 595 599, Elsevier, Amsterdam, 1981.

3) Ohashi N, Watanabe $Y$ and Mizukoshi K : Prediction in smooth pursuit. Acta Otolaryngol (Stockh) $103: 131 \sim 136,1987$.

4) Ohashi N, Watanabe $Y$, Mizukoshi K, et al : An application of the microcomputer as a generator of target movements for the eye tracking test (ETT). Computer Methods and Programs in Biomedicine $23: 243 \sim 246,1986$.

5) 大橋直樹, 渡辺行雄, 水越鉄理, 他 : 滑動性眼 球運動分析一ランダム正弦波の開発と再現性の 検討一. Equilibrium Res 44 : 275 279, 1985.

6) Lisberger SG, Evinger C, Johanson GW, et al : Relationship between eye accelerations and retinal image velocity during foveal smooth pursuit in man and monkey. J Neurohysiol 46 : $229 \sim 249,1981$. 
7) Stark L and Vossius G : Predictive control of eye tracking movements. IRE Transactions on Human Factors in Electronics $9: 52 \sim 55$, 1962.

8) Dollas PJ and Jones RW : Learning behavior of the eye fixation control system. IEEE Transactions on Automatic Control 6:218 227, 1963.

9) Bahill AT, Iandolo MJ and Troost BT: Smooth pursuit eye movements in response to unpredictable target waveforms. Vision Research 20 : 923 931, 1980.
10) Michael JA and Jones GM : Dependence of visual tracking capability upon stimulus predictability. Vision Research $6: 707 \sim 716,1964$.

11) Eckmiller $R: A$ model of the neural network controlling foveal pursuit eye movements. Progress in Oculomotor Research (ed by Fucks AF and Becker W). pp 541 550, Elsevier, Amsterdam, 1981.

$\left(\begin{array}{l}\text { 別刷請求先 : 大橋直樹 } \\ \mathbf{T} 930-01 \text { 富山市杉谷 } 2630 \\ \text { 富山医科薬科大学医学部耳鼻咽喉科学教室 }\end{array}\right)$ 